\title{
TEACHER FRIENDLY E-FLASHCARD: A DEVELOPMENT OF BILINGUAL LEARNING MEDIA FOR YOUNG LEARNERS
}

\author{
Luh Ayu Tirtayani \\ Psikolog, Department of Early Childhood Teacher's Education, Faculty of Education, \\ Universitas Pendidikan Ganesha, Indonesia \\ E-mail: ayu.tirtayani@undiksha.co.id \\ Mutiara Magta \\ Department of Early Childhood Teacher's Education, Faculty of Education, \\ Universitas Pendidikan Ganesha, Indonesia \\ E-mail: mutiara.magta@undiksha.ac.id \\ Ni Gusti Ayu Made Yeni Lestari \\ Department of Early Childhood Teacher's Education, Faculty of Education, \\ Universitas Pendidikan Ganesha, Indonesia \\ E-mail: yenilestari@undiksha.ac.id
}

\begin{abstract}
The study aims to describe the development of process design and validation of learning media 'friendly teacher e-flashcards' through empirical test on a limited group. 'Teacher friendly e-flashcards' is the media that was developed to meet the needs of bilingual learning at the level of early childhood education. The development of educational media is implemented in four stages: a preliminary study, development, evaluation, and reflection as well as documentation. At this stage of development, the content is prepared first and then proceed with the design of the program. Validation of the content and media experts shows that the 'teacher friendly e-flashcards' is being 'very good' for stimulation bilingual early childhood. Furthermore, empirical tests on a limited group (12 kindergarten teachers from four districts in Bali) gave judgment on the category of 'good'. Media 'teacher friendly e-flashcards' is a technology-based educational media that can be used in bilingual teaching of children of kindergarten in Bali. Further media development and empirical testing in a wider group strongly recommended for subsequent research
\end{abstract}

Keywords: e-flashcard, bilingual, early childhood education, research development

\section{Introduction}

English as an international language is really important to be mastered in this globalizations era. It becomes a need to teach it as early as possible, starting from Kindergarten level (Bee \& Boyd, 2007). Considering the need of learning English from the early age, it is important for school to think about the preparation and also an improvement in facing the era. One way that can be done is by bilingually teaching the student from the Kinderganten level.

Lambert (Takakuwa, 2009) found that bilingual children have a higher intelegency score than others who are monolingual. It shown that bilingual learning gave a positive impact to children. Bilingual learning is an educational effort to give a second language or a foreign language to the child. Bilingual learning in early age is an effort to introduce another language, beside Bahasa Indonesia as their first language, through the playing activities. Learning through playing means there will be a fun's learning activities on their classroom. According to Fletta (in Itta, 2007), games I a really valuable for children who learn foreign language. Furthermore, Itta (2007) argued that chidren who starts learning new language need times to adapt with that language, sound, and rhythm. It becomes the reason to provide them an enjoyable situation in learning. Providing games may create a fun atmosphere, so when it implemented during the learning activities, the process of learning can be felt enjoyable. The enjoyable situation of learning will also motivate the stundent well. Children need a motivation and acceptance from their social environment before they try to producing a new language.

However, children need to explore with lots of information and excercises in targeted language. Those informations and excercises can be given by providing listening and speaking words activity with strategy that consider the words quality and quantity in introducing the target language in order to gain 
tangible result in children's bilingualism development (Baker, 2000). In an ethnography study (Arikan, 2015), it is known that the use of visual aid has been implemented in many learning English activity, especially for children.

In other studies, it is known that the use of flashcards is effective in improving student's vocabulary. Flashcards as a media is also effective to teach foreign language for children, especially English. A study which involved second grade students of elementary school shows that there is an improvement of students' vocabulary mastery after taught by using flashcards as a media in learning (Hotimah, 2010). Furthermore, the us of flashcards is not only effective to be used in classroom setting. A case study on a foreign language stimulation done by the mother at home setting shown that flashcards is also works well at home (Lan, Torr, \& Degotardi, 2011).

Penelitian mengenai efektivitas flashcards dalam pembelajaran bahasa asing telah banyak dilakukan. Namun, belum banyak dilakukan penelitian mengenai penggunaan flashcards berbasis teknologi, terutama pada pembelajaran asing bagi anak didik usia dini. Oleh sebab itu, dirancanglah penelitian ini dengan mengembangkan suatu media $e$-flashcards yang sesuai kebutuhan para guru dalam mengajarkan materi bilingual kepada anak usia dini di taman kanak-kanak. Media yang dikembangkan disebut 'teacher friendly e-flashcards'.

Research on the effectiveness of flashcards in foreign language learning has been widely carried out. But, unfortunately it is still a manual paper printed flashcards. In this globalization era, a technology based flashcards can be an alternative solution to introduce language to the children. Therefore, this study was designed to develop electronic-based flashcards to suite the teachers' need of bilingual materials in teaching the kindergartens. The media being developed is named 'teacher friendly e-flashcards'.

\section{Research Objectives}

The purpose of this study was to describe the development process of 'teacher friendly eflashcards', a media of the bilingual learning program to young learners in Bali. This study also had a purposes to describe the validation results of the media on limited empirical test group, which is on six kindergarten in Bali area. The result was a hypothetic form of 'teacher friendly e-flashcards', a learning media in the form of electronic flashcards aired on a computer or other electronic devices.

\section{e-flashcards as a Teaching Media}

Lesle J. Briggs (1979) in Riyana (2004) mentioned teaching media as "the physical means of conveying instructional content...book, films, videotapes, etc”. More detail, Briggs stated media are the tools to stimulate children in order to conduct a learning process. Teaching media is a tool that can be manipulated and can be used to effect students' mind, feeling, attention, and attitude, so it can help the learning process become easier (Muhson, 2010). One of effective media that can be chosen is flashcards (Itta, 2007).

In general, there are three aspects in media, that is sound, visual, and movement. Brets (in Riyana, 2004), stated that there are seven classifications of media, such moving audio visual (example: movie, video, animation, etc), silent audio visual media (such as a movie bundle voice, courtyard noises and sound slide), audio media semi motion (such as: writing is much spoken), visual media moves (such as a silent film), visual media silence (such as printed pages, photos, microphone, slide the mute), audio media (such as: radio, telephone, audio tape) and print media (such as books, modules, independent teaching materials).

Learning media is a tool that can be manipulated and can be used to effect students' mind, feeling, attention, and attitude, so it can help the learning process become easier (Muhson, 2010). One of effective media that can be chosen is flashcards (Itta, 2007). Flascards can be in the form of printed cards with picture in size $25 \times 30 \mathrm{~cm}$. The pictures can be drawn or taken from photos and are sticked in the flashcards pieces. This graphical media is two dimentions media which can be enjoyed and explored by using sense of visions.

In the previous research, there is flashcard developed ito electronic flashcards or commonly said as e-flashcards. It is a graphical media which is technology based. Furthermore, ink this study, that eflashcards is developed into 'teacher friendly e-flashcards'. This media designed to ease the teachers in giving bilingual materials for students in kindergarten and gain the students attention as well. This media can give comfort situation for teachers both in preparing and managing the instruction in classroom.

In this globalization and information era, the development of learning media also becomes fast. The use of information and technology in learning media becomes a demand. However, designing IT based media need a special ability, but it does not mean that IT based media should be avoided to use. There are many kinds of IT based media that can be chosen to help teachers in teaching, they can be in 
form of media taken from internet, application in mobile phones, or media in CD room/flash disk. Based on Muhson (2010), there are 2 main components in IT based media. Those components are Learning Management System (LMS) and Learning Content (LC). LMS is a computer system that can be said like administration staff who will manage the process of teaching and learning. On the other hand, learning content is the learning material it self, which will be delivered to the students. The content in a media should be designed by experts who are competent in a certain subject, and it is not a must for them to be expert in IT. After the content have been designed, then the electronic version will be developed by content developers so it can be inserted to LMS. In this study, media being developed was $e$-flashcards and it is categorized as static audio visual media.

\section{Languages Acquisition on Young Children}

Gracia (as stated in Krisanjaya, 1998) mentioned that children language acquisition can be said having characteristic that is sustainable, having a continuum, and developing from one simple word into a more complicated combination of words (syntax). If we belief that the function of baby crying as the beginning of a child's communication competency, then the utterance of single word which is very individual and unique like "mamam" or "maem" (means eating), can be an indication of the beginning of formal language development. For the next stage of development, children will go to the next level, which is students will face the development of their language acquisition in phonology, morphology, syntax, and semantics.

Furthermore, especially for the relation between children cognitive and language development, there are two things that can be concluded. First, when children can produce sentence with good structure and pattern, it does not automatically mean that they master the language well. Second, as speakers of certain language, children shpuldnachieve cognitive categories which become the basic of natural language expression, like time and space. Lenneberg (1969) stated that the development of language depends on the development of brain biologically. The development of brain can give chance to ideas to be developed too, in which it can cause the development of language acquisition.

Moreover, Steinberg (1990) explained the relation of mind and language. For him, children's mind system is developed bit by bit if there are stimulus from surrounding as input. This input can be from what they hear, see, and touch as a reference to things, events, and situation around them. After a long process, children's mind will be constructed perfectly. When the mind has been constructed well and if the language input is experienced simultaneously with things, events, and situation, language is started to be acquired. After that, the language system will be completed with good vocabularies and grammatical mastery. Some parts of the language system are the mind system because meaning of the language is formed as the idea which belongs to the mind process. The system of mind and language are integrated in the form of meaning and idea.

The first language acquisition of children has close relation with children's social development and because of that, it is close with children's social identity formation (Hurlock, 1993). In order to aquire the first language, there are some aspects that should be considerate, namely time, space, modality, and cause and effect. Those aspects become important parts in children's cognitive development in order to acquire their first language of mother tongue. By acquiring language, especially first language, children learn how to be a society members. Because of that, mother tongue or first language has a role to be the tools for children to express their feeling, desire, belief, ideas, hope, and others. In the process of acquiring language, there are four strategies that are commonly implemented. The first strategy is imitating. There are some imitating process, like spontaneous, acquisition, directly, slow, and expansion. The second strategy is productivity. It means that effectiveness and efficiency in acquiring the language are found from linguistic and nonlinguistic communication, like facial expression, gestures, sounds, etc. The next strategy is feedback, which is feedback between strategy of utterances production and response. The last stretch is what is called by operation principle or standard, including general and special operational principle.

Second language acquisition is when children acquire a new language after mastering their first language or mother tongue in a certain level. There are some experts who belief that second language is the same as foreign language. Experts who agree with the early English stimulation claim that the sooner English is introduced to children, the more chance for them to use it, and the better children will learn it (Rossel \& Ross dalam Papalia et.al, 2008). Supporting that belief, it was found that there are decreasement of effectiveness in learning language from early age children until the end of tennager age (Newport dalam Papalia et.al, 2008).

There are differences in learning first and second language. The process of learning second language has some characteristics, like (Papalia, et.al., 2008): learning language consciously (because it is one of the subject matter in school), it depends on the school condition (the stimulation or the learning 
process), the motivation to learn is not as big as when learn the first language, the limitation of time to learn, the media is provided, and it is organized or managed by people (teacher or school). Those differences show that it is important to plan the learning, including prepare the media well to support children's second language acquisition. The preparation of appropriate media should be an important consideration since the process of learning the second language is done consciously so the students' high motivation is really needed to achieve the learning objectives. In this case, besides considering the effect of media used to develop children's competency in language, it is also a need to consider on the teacher's need as the user of the media in teaching the language.

\section{Constructive Theory in Language Acquisition Process}

The constructive theory was proposed by Piaget, Vygotsky, and Gardner (Bee \& Boyd, 2007). The theory argues that the cognitive development and language are formed by the interaction between children with others. From that interaction, children develop their knowledge, values, and attitudes. When they were at a younger age, children have a limited cognitive ability. But, through the social interaction, they have increased their ability to think. This social interaction includes children experience in learning. As we know, people receive education in their efforts to develop himself as a person and also have a respect as a member of society (social beings). By that experience, children will be able to learn an optimum when they give appropriate learning activities. Therefore, children should get an opportunity to communicate as an experience on their classroom learning activities.

Based on a constructive perspective, language acquisition is important to support the child since the early stage of their life. Language has a primary function as a tool to communicate and interact each other. Children required to be able to convey and express his thoughts, but at the same time, they should be to understand the others (Kementerian Pendidikan Nasional, 2014). Shortly, the constructive theory proposed that the function of language as tools of communicating and thinking. It means that to be a good communicator, the early childhood needs guidance how they acted. Therefore, it is important to stimulate the function of language as tools of thinking as early as we could. For example, children are supported to have an experience how to express their communication skills in the classroom. Children need a guidance to improve their language ability. Teacher, adults or even other older children can take a part in the learning process. Their presence could encourage children to talk. The children also could receive various words and sentences stimulation. The words they received will help the children to use a higher language skill or unleash the language potential that they already have.

As consequence, teachers are suggested to use and choose an interactive and right learning method. The teachers also determine the best learning media to support education process. However, the learning method and media that have been chosen should offer a challenge for the children to communicate. Educators need to improve the quality of learning and teaching technique to attract students. Therefore, teachers should be considering the use of best media and materials in the classroom. In according to improve a language capability, teachers need to provide a media that can stimulate children to communicate and thinking. The children need to think the words/phrase and context/message in their sentence. In the learning process, children also need an attractive media, so they are motivated to achieve a better language skill. In this context, one of the best medium to transfer the learning materials for nowadays learners is an interactive media. Interactive learning media has been proven to improve children's motivation in language learning.

Hurlock (1993) emphasizes that language learning for early childhood is an active interaction. Therefore, there are three sources of learning and teaching should be considered in this class. First, the children themselves as a source of learning and perpetrators. Children need to support for communicate mutually each other. By active interaction methods in the classroom, it believes in improving the children language skills. Second, adults as a teacher or educator. Adults who spoke minimal in the class would not support the development of children's language skill. The child efforts to learn a language can be acknowledged by educator through expression and words. By the words, educators stimulate children to build a higher thinking skill. A higher thinking is stimulated through the conversations among audiences. Educators explore with open-ended questions so that the child can think and response the situation. Based on that experiences, the active educator will give children knowledge how to use the right language for communication. The teachers should make a sentence and talk with a perfect language. If adults' educators give a mistake ways, so the child will imitate those words or sentence for their circumstances. Third, the active neighborhood and circumstance are also the factors for stimulating a student language skills. Adults can put a lot of words in children play zones. It is can support children to see words every time. The child can hear these words that have been spoken by his/her friends. For example: If they see a table, it can be put the words with the spell "m e $\mathrm{j}$ a" (means table) on the table. Active educators will 
bring the rich language spirit into the child's mind. They also have a chance to put out the child's mind through the spoken language. Thus, the children knowledge will continue to grow.

Children have to achieve a better language proficiency through their experience. It is important because a language has many functions and one of them is a function of information (Halliday in Suhartono, 2005). The development of information's function is the slowest one. However, this function is the most widely used in theirs later environment. One of them is the school environment. Language as a function of information is a function to give something such knowledge or information to others. The proficiency of foreign language, in this case of English, has become a cultural capital for a child to communicate with others. English skill also becomes a capital in order to build their knowledge about the environment. Children will be able to respond global developments and the changes if they have a good skill in English.

\section{Methodological Approach}

This development research or also known as research design (RD) is a research methods used to produce a particular product (van den Akker, 1999). This research is classified as a educational research development, conducted a systematic study in designing, developing, and evaluating an educational interventions, as an answer to the complex problems in the practices field of education (Plomp, 2007). Reeves' (2006) design was adapted in this study, including: the analysis field, designing and developing products, repeatedly evaluation, reflection and revise. This research was conducted in four stages, ie: the preliminary study stage, the development stage, the evaluation stage, and the stage of reflection and documentation (Nieveen, McKenney, \& van den Akker, 2006). At the development stage, the product of 'teacher friendly e-flashcards' validated by expert of content and media. Furthermore, at the evaluation stage, this media carried out in a limited groups of assessors, twelve kindergarten teachers from four districts in Bali. The results are converted into five levels of products achievement scale (Agung, 2012).

\section{Results}

\section{Preliminary Study Phase}

Three activities are conducted at the stage of preliminary study namely literature review and evaluation of the first-year prototype research results, a fieldwork focused on the learning process in the classroom and analysis syllabus of subjects used, and the last activity is problem identification of learning process in the kindergarten that arose during the fieldwork. There are some requirements defined at this stage. The first requirement is the availability of contextual bilingual instructional media for early childhood. The second requirement is the availability of instructional media that have able to stimulate English proficiency according to the learning themes of kindergarten. The kindergarten teachers hope that there are a thematic bilingual instructional media that suitable for the theme of learning in 2013 curriculum. The third requirement is the existence of attractive bilingual instructional media, by combining images and sound. That means that there is a need for a technology-based learning media. The fourth requirement is the availability of bilingual instructional media that can provide stimulation speak properly. As a result, the need for appropriate media content indicates stimulation of the ability to receive and pronounce sentences in English. The last requirement is the media that is effortless operated by the educators.

\section{Development Phase}

E-flashcards application was developed using software called Adobe Flash CC 2015. The software is very suitable because it is easy to use and has a feature that allows programmers to create animations to complement this material, as well as the installer file, is generated relatively small capacity. Sound audio material or edited using Audacity application. This application allows programmers to cut the sound and store the voice files in the form of extensions mp3 - is an audio coding format for digital audio. Component images in e-flashcards are edited using Adobe Photoshop CS6. This application makes the result have the same size with the original images.

The following are examples of activities offered by 'teacher friendly e-flashcards' accompanied with a brief guide of operation in the learning process.

1. The main page

On the main page, there are 4 menus which is a theme in the $e$-flashcards. 


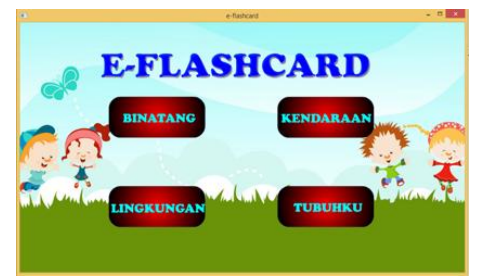

2. The page menu on the theme of Lingkunganku (My Environment) (example) On this page, there are 3 menu themes, namely: nature around me (alam sekitarku), my home (rumahku), and school (sekolah). If one option is pressed it is going to the introduction page. At the left bottom, there is a back button to go to the main page.

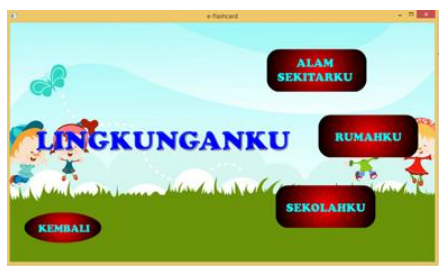

3. Introduction page

On the introduction page will display the image recognition is given. The image is given an explanation in the form of a name in Indonesian, English, sentences in Indonesian, and sentences in English. Here is an example page introduction:

a. The word introduction in Bahasa Indonesia

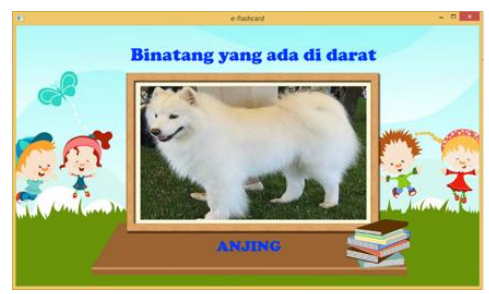

b. The word introduction in English

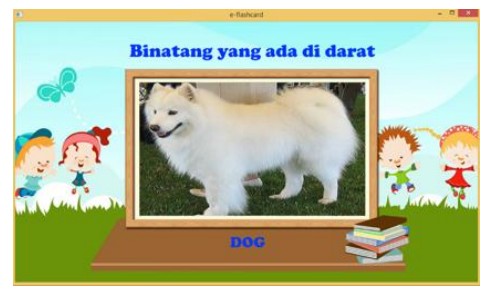

c. The sentence introduction in Bahasa

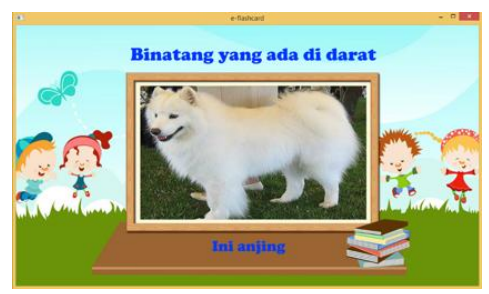


d. The sentence introduction in English

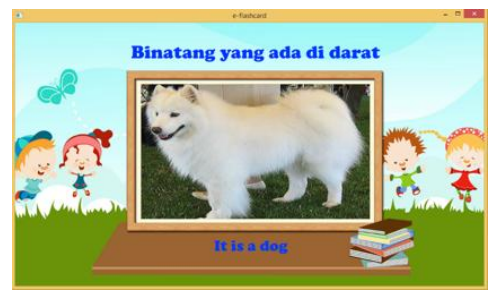

4. The complete introduction's page

The left bottom on the introduction page, there is back button option (kembali) to the main page.

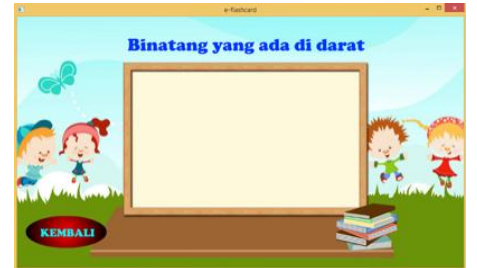

The experts' validation of the content of the early childhood bilingual learning was obtained 95\% (excellent). These experts assessed that the 'teacher friendly e-flashcards' media have a capability to load a real variety setting or situation faced by early childhood. This condition is suitable for the need of children to learn a language in bilingual, it means that the need is more contextual to their circumstances daily. The media was assessed capable of optimizing a child's potential learning. It shows by they capacity to mentions the word, but also stimulates to create a simple bilingual sentence. The capability, of course, is able to satisfy the children needs for learning. By using the media, children are going to motivate to use the media in their learning process. The proper of e-flashcards material with teacher's lesson plan have been met as well, so it is worth the media as 'teacher friendly e-flashcards'.

Expert validation of the product of teacher-friendly-e-flashcards as a learning medium showed in the grade of $92 \%$ (excellent). The instructional media experts highlight the excellent ability of the media's e-flashcards in terms of simplicity, complete images with a sub theme of learning, as well as the suitability of the display with the early childhood category. The three aspect of e-flashcards capability is support for the need of bilingual learning process in early childhood education. Based on the assessment of simplicity and usability by educators/teachers, 'teacher friendly e-flashcards' can be understood as a friendly learning media for early childhood.

\section{Evaluation phase}

The field testing was conducted on a limited basis of six kindergartens (Taman Kanak-Kanak) in Bali province, Indonesia. These kindergartens are TK Negeri Pembina Singaraja, TK Pembina Karangasem, TK Negeri Pembina Gianyar, TK Negeri Pembina Tabanan, TK Tunas Kartini 1 Culik in Karangasem, and TK Tunas Mekar 2 in Kerambitan Tabanan. The assessment was involved two teachers from each kindergarten so that overall the media of 'teacher friendly e-flashcard' are evaluated by twelve teachers.

The teachers were assessing the ten indicators of content and media components of the "teacher friendly e-flashcards'. Each indicator also has five range of scores, with a value of 1 means poorly and 5 means excellent. The Ideal maximum score based on teachers' assessment is 50 . The percentage of assessment, limited for field evaluation of 'teacher friendly e-flashcards', is $87 \%$. In general, it means that the 'teacher friendly e-flashcard' can be classified as a good learning medium to stimulate students' bilingual capability in kindergarten. A limited assessment indicates that the ability of media is classified Good. In addition, the teachers also assess that the media is needed for a learning process in today's bilingual classes. Here are the results of teachers' assessment based on each indicator. The first indicator, the suitability of the theme and sub-theme that covered by the media rated at $91.67 \%$ (Excellent) with a range scores between 4 to 5 . The second indicator, the attractiveness display of menus, submenu, and images of the media is rated at $91.67 \%$ with a range scores from 4505 (Excellent). The third indicator, the balancing of background color with images and transcription covered by media is rated at $78.33 \%$ 
(Good) in the range score 3 to 5. The fourth indicator is an impression suitability of e-flashcards with early childhood developmental phase rated at $88.33 \%$ (Good). The data stand on the score range of 4 to 5. The fifth indicators, completeness image of media with the sub-theme of a learning process, was rated by the teachers at $81.67 \%$ (Good) and the score range is 3 to 5 . The sixth indicator is the suitability of the media with lesson plans was rated at $86.67 \%$. The range of score of indicator six is 3 to 5 . The seventh indicator, the suitability of images size, colors, types of transcription of the media with the stage of child development was rated at $88.33 \%$ (Good). It stands of the score between 3 to 5 . The eight indicator is a compatibility between e-flashcard and bilingual materials for the child circumstances covered by 'teacher friendly e-flashcards' was rated at $90 \%$ (Excellent) and it stands for score 4 to 5 . The ninth indicator, bilingual material conformity with the tasks of early childhood language development was rated at $85 \%$ (Good) with a range of scores 4 and 5. The last indicators is a simplicity to operate the media by teachers in the process of learning was rated at $88.33 \%$ with a range of scores are 4 to 5 .

\section{Reflection and 'Teacher Friendly E-Flashcards' Product Documentation Phase}

The reflection of this learning media is the need to take into account the variation of the syllabus as a guide in the choice of materials between an early childhood (PAUD). It should be doing because there is a determination of various sub-theme among kindergarten. In further research, it important to provide a wide range of sub-themes which are able to fulfill the need of kindergarten. The design of images and sounds of the media needs to be a concern because it will be different between early childhood and others age groups needs. Variations of the background of media and the selection of interested, firmly and ignited colors to invoke the emotions atmosphere need precedence.

Reflection also conducted based on the teacher information. Most teachers confirmed that the presence of 'teacher friendly e-flashcards' media is able to meet the needs of educators' bilingual program. Teachers also agree that the 'teacher friendly e-flashcards' are an interesting media for early childhood. It is because the media offers thematic material in kindergarten. The operation of media is effortless and it can be modified according to the classroom needs.

\section{Discussions}

Overall it can be seen that the assessment of the bilingual e-flashcards hypothetical media in the category of Good. Assessment by experts shows that content was rated at $96 \%$ and media at $92 \%$, both of them are in the excellent category. The overall percentage of experts' judgments is $94 \%$ which means that the media 'teacher friendly e-flashcards' was rated excellent and it can be applied in the process of learning. Meanwhile, the percentage of limited groups of assessors was $87 \%$. The scores are given varied from a range of 3 to 5 . It is indicated that the media is rated as Good, in specific it has capabilities as a medium of learning to stimulate of early childhood English skills in kindergarten in Bali.

Media Flashcards media is offered as a solution in bilingual learning because the media is effective to stimulate a children's language abilities. The use of flashcards can improve word recognition in children with learning disorders. The research is conducted by Higgins, McLaughlin, Derby, and Long (2012) applies the flashcards media to improve vocabulary skills for children with autism syndrome. As a result, the study proves that the implementation of flashcards on the learning process for the subject with autism syndrome is able to more focus than before and have a greats motivation to learn. The other research organized by Wopschall, Weber, McLaughlin, Derby and Waco (2014) showed that the ability of recognition, that raised by children through its success to reproduce a memory of word/phrase, increases concomitant with the use of flashcards in the learning process. The recognition ability has a tendency to persist when the evaluation study is conducted in the follow-up phase. It represents an excellent memory retention for children with autism disorders. The use of flashcards to be effective because it has capabilities to allows children to see the images and also the words that represent the image. Therefore, media flashcards can improve students' ability to learn English as a foreign language (Aliponga \& Johnston, 2013; Konomi, 2014). Visual stimulation provides an assistance to students to recognize and understand the language being spoken. This visual aid that increases children's memory of the words in English. Media flashcards bring the positive perception for successful the child when they answer the question, while it will enhance they motivation to learn English.

The implementation of flashcards on learning setting helps students to aware about new information. One thing emphasized is the usefulness and ability of the flashcards presence to repetition an opportunity that has been presented previously. Repetition can be formulated until the child is able to understand the material, with specific intervals for the success of these objectives (Kornell, 2009).

The media developed in this study is a technology-based media. The use of electronic media in the learning process is believed to meet the needs of interest and interactive learning for the children. In 
today's digital era, the use of electronic media in learning can introduce children to the importance of technology in everyday human activities. Other functions, the use of technology in the classroom as well as a children's adaptation efforts undertaken to the need knowledge and operating skills with technological tools in the future (Turgut, Tunga, \& Kisla, 2016).

Byrd and Lansing (2016) supports the implementation of technology in the classroom. On the use of electronic flashcards (e-flashcards), it was found the strong effective impact to build the ability of words acquisition (vocabulary) and to raise memory storage of students. In practical exploration studies, the use of computer-based flashcards compared with the paper-based (traditional flashcards) in the language setting of learning and teaching as a second language. Through the design of pre/post-test, the data showed a significant difference of the ability for acquisition and storage of new words to the group of children that have been received a second language learning through the media of e-flashcards. The media is suggested as the media language learning conducted in the classroom. Similar support was also obtained by Nakata (2008) study. The study is emphasizing that there is a significant change in the use of computers in the stimulation of the child's vocabulary. The result is certainly related to the teachers' assessment, in which 'teacher friendly e-flashcards' are a good medium in an effort of English learning to students in the kindergarten.

The 'teacher friendly e-flashcards' offer a visual stimulation to the students to improve their English vocabulary. The visual media is able to help children study the words of a foreign language that they have been studied. Media that provides visual stimulation assist children in improving the understanding of the topic. Through finding similarities and differences that are characteristics by a word or a phrase (Krcelic \& Matijevic, 2015; Phillips, 2016). Process distinguish and find the equation shows the children's ability to create a group or category of a word, as consequence in the end of learning process the child is easier to bring back the vocabulary appropriate based on the stimulus that they receive.

Furthermore, 'teachers friendly e-flashcards' not only offer visual stimulation, but also audio stimulation (pronunciation). The child can see pictures and transcription that describe the content of images, as well as listen to the pronunciation correctly. Visual and sound stimulation can support the children in recognize the vocabulary of a foreign language, which in this case is English. Schmitt (2008) found that children's ability to remember new words in a second language that they have been learned is very good when the media used is able to provide visual and audio stimulation. Visual stimulation can be creating with the pictures and writing, and it accompanied by a proper pronunciation of audio stimulation. Further, it can be explained that there is no difference whether this is the first language acquisition or whether a second language, if the requirements of readiness protégé, as the foundation of the learning process, indeed have been fulfilled. In line with such research, the stimulation is capable to offered by 'teacher friendly e-flashcards' is very appropriate in an attempt acquisition of English in children kindergarten in Bali. English, in this case, serves as a foreign language. The stimulation in the form of English vocabulary pronunciation reduces the likelihood of errors reception of audio information by children. In Fact, the research found that some of the educators who pronounce English vocabulary are not precise. This condition is impacted to the children reception when they receive and store an erred information that is produced by educators. Therefore, e-flashcards will improve the effectiveness of the understanding of a foreign language to the students in kindergarten.

The children language stimulation offered by this media is suitable to the characteristics of the child's ability to utter the phrase with a complete structure (Bee \& Boyd, 2007). According to the stages of child development, the ability is generally achieved by children of kindergarten age (4-6 years) is to recognize and pronounce the everyday sentence that used in the daily activities. This sentence can show the child attempts to convey their needs, as well as in the process of thinking about the environment. In learning the mother tongue, of course, that everyday sentences obtained child can have a complete structure. However, the stimulation of bilingual children in a foreign language (stimulation of English proficiency as developed in this study) as a complement in interaction with other individuals who use English. Therefore, it is not a complete sentence with structures that are stimulated in this medium, but it suitable for the needs of the daily children. Sentences are offered includes the subject-predicateobject/information. For example: "It is a dog" (meaning it's a dog). This sentence is served for children in Bali can easily find the dog in the surrounding their natural environment. Other activities are also presented such as: sweeping, washing the dishes or cooking, which is also the daily activities of children in their circumstances.

Selection of contextual material to stimulate the English proficiency supports the increased of vocabulary in early childhood education. Children received new information in the forms of English vocabulary, but with the context that easily found in everyday life. 'Teacher friendly e-flashcards' is including the environment around the children (contextual) so that they have an opportunity to express newly vocabulary. In this case, the child not only receives but also have the opportunity to express or 
produce the vocabulary in everyday settings. The chance of receiving an input and output will help the children to more easily understand with their new experience in language learning (Haratmeh, 2012). Opportunities tasks with input and output make children able to apply his understanding of the new language. Vocabulary and language understanding will increase together with the opportunity to use in everyday life. The use of images and materials as a stimulate, 'teacher friendly e-flashcards', reflect that the circumstances of Balinese society are a positive thing to support of foreign language learning in kindergarten.

The assessment of kindergarten teachers to the easier use of 'teacher friendly e-flashcards' indicator in the process of learning is $88.33 \%$ with range scores are 4 to 5 . An overall kindergarten teacher gave judgment on good category, with above-average distribution. A good assessment showed a positive perception of a kindergarten teacher with the use of 'teacher friendly e-flashcards' in the process of English learning in the classroom. Electronic media is proved to be an effective introduction, but not all educators, especially at the level of early childhood education (PAUD) will give the same assessment. Furthermore, not all of teachers will use technology-based learning media in their class. The use of technology-based media in the early childhood learning classes are largely determined by the beliefs held by teachers on that media (Blackwell, Lauricella, Wartella, Robb, and Schomburg, 2013). Confidence and positive attitudes of teachers about the outcomes to be obtained from the child's use of technology can significantly affect the decision of teachers in the use of technology-based learning media in its class. Thus, the use of electronic media in kindergarten is determined by the teacher's reception about the usefulness of technologies for the increase an outcome of children's learning.

The acceptance of kindergarten teachers on 'teacher friendly e-flashcards' media in Bali is showing their confidence and positive attitude of educators on the increase of English proficiency to be achieved by the students later. Along with the development of technology in education, the positive attitude of teachers would open up opportunities for children to benefit from electronic media or multimedia. In the future, confidence and positive attitudes of teachers towards technology are expected to facilitate teachers to choose or develop their own appropriate technology in bilingual learning for young students.

\section{Conclusion}

'Teacher friendly e-flashcards' is generally rated as a good media for bilingual learning by kindergarten's teacher in Bali. The teacher's acceptance is $87 \%$, with the score distributed from 3 to 5 . The score show that the media of 'teacher friendly e-flashcards' was proper used as a technology's based learning media to develop foreign language skills, especially English, to the kindergarten. The research was conducted in four phases: a preliminary study, development, evaluation, and reflection and documentation. At the phase of development, the media are validated by subject matter experts and instructional media experts, based on the main components of learning media, ie. learning management system and learning content. Furthermore, empirical tests on limited groups or small group was conducted at the evaluation phase. The empirical test involves 12 kindergarten's teachers in four districts in Province of Bali.

\section{Acknowledgement}

This research was funded by DIPA Faculty of Education, Universitas Pendidikan Ganesha, fiscal year of 2016

\section{References}

Agung, A.A.G. (2012). Metodologi Penelitian Pendidikan. Singaraja: Universitas Pendidikan Ganesha Aliponga, J. \& Johnston, C.C. (2013). Benefits of Using Vocbulary Flash Cards in an EFL Classroom. Summary of Research, 14, 1-6

Anonim. (2010). Bahan dan Media Pembelajaran Kelompok Bermain. Dalam Pengembangan Konsep Pengetahuan Bahasa Pada Lembaga Kelompok Bermain. Kementrian Pendidikan Nasional Direktorat Jendral Pendidikan Nonformal dan Informal Direktorat Pendidikan Anak Usia Dini.

Arikan, A. (2015). An autoethnography of teaching English to young learners: from theory to practice. Anthropologist, 20(1,2), 77-85

Baker, C. (2000). A Parents' and teachers' guide to bilingualism. second edition. Clevedon.Boston. Toronto. Sydney: Multilingualmatters Ltd. 
Bee, H. \& Boyd, D. (2007). The Developing Child. 11 edition. Boston: Allyn and Bacon

Blackwell, C.K., Lauricella, A.R., Wartella, E., Robb, M., \& Schomburg, R. (2013). Adoption and use of technology in early education: The interplay of extrinsic barriers and teacher attitudes. Computers \& Education, 39, 310-319. http://dx.doi.org/10.1016/j.compedu.2013.07.024

Byrd, D.R. \& Lansing, B. (2016). Electronic flashcards inside the classroom: Practical and effective. The Journal of Language Teaching and Learning, 6(2), 1-13

Cepi, R. (2004). Strategi implementasi Teknologi Informasi dan Komunikasidengan menerapkan Konsep Instructional Technology. Jurnal Edutech. Jurusan Kurtek Bandung.

Dardjowidjojo, Soenjono. (2000). Psikolinguistik: Pengantar Pemahaman Bahasa Manusia. Jakarta: Yayasan Obor.

Gobyah. (2003). Pengenalan Kearifan Lokal Indonesia. Rineka Cipta: Jakarta.

Haratmeh, M. S. (2012). Involvement load and task type in task effectiveness: Two aspects of vocabulary knowledge. International Journal of Academic Research, 4(4), 86-95.

Higgins, M., McLaughlin, T.F., Derby, K.M., \& Long, J. (2012). The differential effects of direct instruction flashcards on sight word identification for two preschool students with autism spectrum disorders. Academic Research International, 2(3), p.394-404

Huda, N. (1999). Pengajaran Bahasa Inggris di Indonesia Perkembangan dan prospeknya. Bahasa dan Seni, 27, Februari, 1-17.

Hurlock, E.B. (1993). Perkembangan anak. Jilid I. Jakarta: Erlangga.

Itta, T. (2007). Kemampuan Berbahasa Inggris Anak dengan Pembelajaran Bilingual. Jurnal Pendidikan Penabur - No.09/Tahun ke-6/Desember 2007.

Jalongo, Mary Renck. (2007). Early Childhood Language Arts. USA: Pearson Education, Inc.

Kemendiknas. (2010). Pedoman Pengembangan Program Pembelajaran di Taman Kanak-kanak. Jakarta: Dirjen MPDM, Dirjen PTKK dan SD.

Konomi, D.K. (2014). Using Visual Materials in Teaching Vocabulary in English as a Foreign Language Classrooms with young learner. Dalam Proceeding of 3rd International Conference New Perspective in Science. Italia: Libreriauniversitaria.It. ISBN. 978-88-6292-469-6

Krcelic, P. \& Skledar Matijevic, A. (2015). A picture and a thousand words: Visual tools in ELT. The Internasional Conference on The Importance of Learning Professional Foreign Languages for Communication between Cultures. p. 110-114. 18 - 19 September 2015, Zagreb-Croatia

Kristianty, Theresia. (2006). Pandangan-Pandangan Teoritis Kaum Behaviorisme tentang Pemerolehan Bahasa Pertama. Jurnal Pendidikan Penabur - No.06/Th.V/Juni.

Lan, Y.C, Torr, J., \& Degotardi, S. (2011). Learning English as a Foreign Language at Home: The practices of Taiwanese mothers and their pre-schoolers. Journal of Modern Education Review, 1(1), p. $10-21$

Muhson, Ali. (2010). Pengembangan Media Pembelajaran Berbasis Teknologi Informasi. Jurnal Pendidikan Akuntansi Indonesia, Vol. VIII. No. 2, 1-10.

Nakata, T. (2008). English vocabulary learning with word lists, word cards and computers: Implications from cognitive psychology research for optimal spaced learning. ReCall 20(1), 3-20. http://dx.doi.org/10.1017/S0958344008000219

Nieveen, N. McKenney, S., \& van den Akker, J. (2006). Educational Design Research: The value of variety. In J. van den Akker, K. Gravemeijer, S. McKenney, \& N. Nieveen. Educational Design Research (p.151-158). New York: Routledge

Nyamai-Kisia, C. (2010). Kearifan Lokal dan Pembangunan Indonesia. http://phenomenaaroundus/2010/06/kearifan-lokal-dan-pembangunan.html

Papalia, Diane E., Sally Wendkos Olds, dan Ruth Duskin Feldman. (2008). Human Development (Psikologi Perkembangan) Bagian I s/d IV. Jakarta: Kencana Prenada Media Group.

Phillips, M. (2016). The Effects of Visual Vocabulary Strategies on Vocabulary Knowledge. Theses, Dissertations and Capstones. Paper 987

Plomp, T. (2010). Educational Design Research: An introduction. In J. van den Akker, B. Bannan, A.E. Kelly, N. Nieveen, \& T. Plomp. An Introduction to Educational Design Research (p. 9-36). Enschede: SLO

Reeves, T. (2006). Design research from a technology perspective. In J. van den Akker, K. Gravemeijer, S. McKenney, \& N. Nieveen. Educational Design Research (p.52-66). New York: Routledge

Cepi Riyana, 2004, Strategi implementasi Teknologi Informasi dan Komunikasi dengan menerapkan Konsep Instructional Technology, Jurnal Edutech, Jurusan Kurtek Bandung.

Santrock, John W. (2002). Life Span Development (Perkembangan Masa Hidup), Edisi kelima, jilid 1 , Jakarta: Erlangga.

Santrock, John W. (2008). Psikologi Pendidikan. Jakarta : Kencana Predana Media Group. 
Schmitt, N. (2008). Instructed second language vocabulary learning. Language Teaching Research, 12(3), 329-363. doi: 10.1177.1362168808089921

Sudono, A. (2000). Sumber belajar dan alat permainan. Jakarta: Grasindo.

Suhartono. (2005). Pengembangan Keterampilan Berbicara Anak Usia Dini. Departemen Pendidikan Nasional Direktorat Jendral Pendidikan Tinggi Direktorat Pembinaan Pendidikan Tenaga Kependidikan dan Ketenagaan Perguruan Tinggi.

Takakuwa, M. (2000). "What's wrong with theconcept of cognitive development in studiesof bilingualism". Dapat dibuka pada http://www.questia.com.

Tim Penyusun Kamus Pusat Pembinaan dan Pengembangan Bahasa. (1996). Kamus Besar Bahasa Indonesia. Edisi Kedua, Balai Pustaka: Jakarta.

Turgut, G., Tunga, Y., \& Kisla, T. (2016). Technology education in preschool: an applied sample lesson. International Journal on New Trens un Education and Their Implications, 7(1), p.81-92

van den Akker, J. (1999). Principles and methods of development research. In J. van den Akker et al. (Eds.), Design approaches and tools in education and training (pp. 1-14). Dordrecht: Kluwer Academic Publishers.

Wopschall, J., Weber, K.P., McLaughlin, T.S., Derby, K.M., \& Waco, T. (2014). The effects of the model, lead, test error correction with flashcards for teaching a student with learning disabilities first grade sight words. International Journal of English and Education. 4(3), p. 541-556 